\title{
The influence of dietary fat on fat metabolism and body fat deposition in meal-feeding and nibbling rats
}

\author{
By J. D. WOOD* and J. T. REID \\ Department of Animal Science, Cornell University, Ithaca, New York, USA
}

(Received 3 June I974-Accepted 4 December 1974)

\begin{abstract}
1. An experiment was done with rats (body-weight $\mathrm{I} 60 \mathrm{~g}$ ) to study the effects on fat metabolism and body composition of low (ro $\mathrm{g} / \mathrm{kg}$ )- or high ( $\mathrm{r} 40 \mathrm{~g} / \mathrm{kg}$ )-fat diets fed as one meal for one $4 \mathrm{~h}$ period/d (meal-feeders) or as six spaced meals/d (nibblers). The daily energy intake/unit metabolic body-weight (body-weight ${ }^{0.73}$ ) was the same for all four groups, and this level of intake was about $80 \%$ of that consumed by rats allowed unrestricted access to the low-fat diet. The experimental period was $76 \mathrm{~d}$.

2. Rats given the high-fat diet deposited more body fat/d and, as a result, grew faster and were energetically more efficient than rats given the low-fat diet. The high-fat diet depressed de novo lipogenesis from glucose in epididymal and perirenal fat pads, whose fatty acid composition resembled that of the diet.

3. For both diets meal-feeders had greater stomach plus small intestine weights than nibblers and had higher plasma free fatty acid levels, when they were killed i $5 \mathrm{~h}$ after their last meal.

4. Meal-feeders given the low-fat diet had the greatest rate of lipogenesis for fat pads.

5. Meal-feeders given the high-fat diet deposited less of the main dietary fatty acids in their fat pads.

6. There was no evidence that meal-feeders eating a high-fat diet adapt their metabolism so completely that they become more efficient utilizers than those nibbling this diet. Mealfeeders eating the low-fat diet became no fatter than nibblers of this diet, possibly because they were eating less than their daily ad lib. intake.
\end{abstract}

When rats eat their daily food as one meal (meal-feeders) instead of several smaller meals (nibblers), it benefits them to regulate their fat metabolism so that the maximum amount of food can be stored while it is available, to be used as a source of energy during the period when it is not available. This applies to rats eating diets with low or high fat contents. Rats meal-fed with low-fat diets were found to have increased activity of the adipose-tissue enzymes involved in the conversion of carbohydrate to fat (Hollifield \& Parson, I962), and, if the total energy intake is sufficient, the result is increased body fatness (Cohn, Shrago \& Joseph, 1955). Rats eating high-fat diets, however, do not rely on carbohydrate as a substrate for body fat; instead they incorporate dietary fat directly into fat stores, which is energetically a more efficient process; this also leads to greater fatness (Schiemann, 1969). It has not been established, however, whether this incorporation becomes more efficient when high-fat diets are meal-fed, possibly as a result of adaptation of the enzymes involved in the conversion of dietary fat to body fat, and whether even greater fatness is obtained with meal-fed rats than with nibblers. It is not really relevant that the substitution of a low-fat for a high-fat diet removes the increased lipogenesis from carbohydrate (Leveille \& Hanson, i 966) as carbohydrate becomes an unimportant source of body fat. We there-

* Present address: Department of Biochemistry and Physiology, ARC Meat Research Institute, Langford, Bristol BSI 8 DDY. 
fore decided to compare fat metabolism and body fatness in nibbling and meal-fed rats given isoenergetic amounts of low-fat or high-fat diets, to determine the extremes of body fatness.

\section{EXPERIMENTAL}

\section{Animals, diets and experimental design}

Fifty-two male Sprague-Dawley rats (50-d-old, mean body-weight $\mathrm{x} 60 \mathrm{~g}$ ) were used in the experiment. Of these, twelve were killed to obtain representative values for body composition ('initial slaughter' group). The remaining forty rats were divided randomly by weight into four groups of ten and were treated as follows: group I was given the low-fat diet as one meal (one $4 \mathrm{~h}$ period) daily (low-fat meal-feeders, LFMF); group 2 was given the low-fat diet as six separate meals (low-fat nibblers, LFN); group 3 was given the high-fat diet as one meal daily (high-fat meal-feeders, HFMF); group 4 was given the high-fat diet as six separate meals (high-fat nibblers, HFN). The diets (Table I) were designed to stimulate (low-fat) or reduce (high-fat) de novo lipogenesis (Jansen, Hutchison \& Zanetti, I966). The meal-feeders were fed between 20.00 and 24.00 hours and the nibblers at 08.00, I I.00, 15.00, I 7.00, 20.00 and 24.00 hours. Each of the rats in groups 2, 3 and 4 had the same energy intake/unit metabolic body-weight (body-weight $(W)^{0.73}$ ) per $d$ as that obtained the previous day for a rat from group $\mathrm{I}$. The rats were weighed daily at 08.00 hours and when they reached a mean body-weight of approximately $300 \mathrm{~g}$, each 'pair-fed' group of four rats was killed. The rats were housed singly at $22^{\circ}$, water was freely available and they were exposed to alternating $\mathrm{I} 2 \mathrm{~h}$ periods of light (08.00-20.00 hours) and darkness.

The rats were killed by decapitation, $15 \mathrm{~h}$ after their final meal (at 24.00 hours). Water was available to them during the starvation period. Blood was collected in heparinized containers and plasma was obtained by centrifuging the blood samples at I $500 \mathrm{~g}$ for $15 \mathrm{~min}$.

\section{Chemical analysis of bodies and tissues}

The empty bodies of the rats (gut contents removed) were frozen, freeze-dried and ground, using a Wiley mill with solid $\mathrm{CO}_{2}$. The empty stomachs and small intestines were weighed, freeze-dried, and subsequently added to the empty body of the appropriate rat before grinding. The amounts of nitrogen and diethyl ether-extractable material for the freeze-dried, powdered material were then estimated (Association of Official Agricultural Chemists, 1955). 'The chemical composition of the epididymal and perirenal fat pads from the rats was determined separately. An adiabatic oxygen bomb calorimeter was used to determine the energy content of the bodies and fat pads and also that of the diets, faeces and urine.

The rats in the 'initial slaughter' group were weighed at 08.00 hours on the first day of the experiment (after $8 \mathrm{~h}$ starvation) and were killed after $\mathrm{I}_{5} \mathrm{~h}$ starvation when empty-body-weight (EBW) and subsequently empty-body composition were obtained. Equations were derived to estimate EBW and empty-body composition of the rats in the four main experimental groups from their body-weight at $08.00 \mathrm{~h}$ on the first day of the experiment. 
Table I. Composition of experimental diets given to rats

Ingredients* $(\mathrm{g})$
Gluicose
Casein
DL-methionine
Maize oil
Minerals†
Vitamins $\$$
Total
Chemical analysis
Crude protein (nitrogen $\times 6 \cdot 25)(\mathrm{g} / \mathrm{kg})$
Water $(\mathrm{g} / \mathrm{kg})$
Diethyl ether extract $(\mathrm{g} / \mathrm{kg})$
Ash $(\mathrm{g} / \mathrm{kg})$
Gross energy $(\mathrm{MJ} / \mathrm{kg} \mathrm{dry} \mathrm{matter)}$
Crude protein $(\mathrm{N} \times 6 \cdot 25)(\mathrm{g} / \mathrm{MJ})$

$\begin{array}{rr}\text { Low-fat } & \text { High-fat } \\ 770 & 590 \\ 180 & 220 \\ 2 & 2 \\ 10 & 140 \\ 30 & 40 \\ 10 & 15 \\ 1002 & 1007\end{array}$

Chemical analysis

Crude protein (nitrogen $\times 6.25)(\mathrm{g} / \mathrm{kg}) \quad$ 16I

Water $(\mathrm{g} / \mathrm{kg})$

Diethyl ether extract $(\mathrm{g} / \mathrm{kg})$

Gross energy ( $\mathrm{MJ} / \mathrm{kg}$ dry matter)

Crude protein $(\mathrm{N} \times 6.25)(\mathrm{g} / \mathrm{MJ})$

$\begin{array}{rr}161 & 193 \\ 82 & 64 \\ 9 & 128 \\ 25 & 35 \\ 16.8 & 22 \cdot 0 \\ 10.4 & 9.5\end{array}$

* Dietary components were obtained from General Biochemicals Inc., Chagrin Falls, Ohio, USA, except where indicated otherwise.

$\dagger$ Jones-Foster complete mineral mix (General Biochemicals Inc., Chagrin Falls, Ohio, USA).

$\ddagger$ Complete vitamin mix (Nutritional Biochemicals Corp., Cleveland, Ohio, USA).

\section{Determination of metabolizable energy (ME)}

Twenty rats of the same strain, age and weight as the experimental animals were divided into four groups of five each, and were then given the same diets at the same feeding frequencies as the animals in the main experiment. The energy intake of these rats was regulated as described previously. After 2 weeks in metabolism cages equipped with facilities for collecting urine and faeces separately, a $7 \mathrm{~d}$ period in which these materials were quantitatively collected was begun. Urine was preserved in I $\mathrm{M}-\mathrm{HCl}$. Urine and faeces were stored at $-20^{\circ}$ before freeze-drying for subsequent energy determinations.

\section{Fat metabolism studies}

At the time of slaughter, portions (100-200 $\mathrm{mg}$ ) of the epididymal and perirenal fat pads were removed immediately for lipogenesis studies (O'Hea \& Leveille, I968). The incubation medium was calcium-free, Krebs-Ringer bicarbonate buffer $(2 \cdot 4 \mathrm{ml} /$ flask) containing $(/ \mathrm{ml}): \beta-\mathrm{D}-\left[\mathrm{U}-{ }^{14} \mathrm{C}\right]$ glucose $0.25 \mu \mathrm{Ci}$ in $5 \mu \mathrm{mol}$ carrier, insulin (recrystallized bovine pancreas, batch no. 901709, $26 \mathrm{IU} / \mathrm{mg}$; Calbiochem, Los Angeles, California) O.I IU. This high level of insulin was used for maximal stimulation of lipogenesis for all groups. This is particularly important as plasma insulin concentrations and insulin sensitivity in adipose tissue are reported to increase in LFMF rats (Wiley \& Leveille, I970). Preliminary studies had also shown that these incubation conditions overcame any inhibition of lipogenesis due to the $15 \mathrm{~h}$ starvation period. After the $2 \mathrm{~h}$ incubation period, lipogenesis was stopped by adding $0.25 \mathrm{ml} 0.5 \mathrm{M}-\mathrm{H}_{2} \mathrm{SO}_{4}$. Lipid from the tissues was extracted and purified using the procedure of Folch, Lees \& Sloane Stanley (1957). The extracted lipid was then dissolved in a toluene-based scintillation solution (O'Hea \& Leveille, 1968) for the determination of its radioactivity content. 
Table 2. Initial and final empty-body-weights $(E B W)$ and energy intakes for rats given isoenergetic amounts of low-fat $(L F)$ or high-fat $(H F)$ diets as six spaced meals (nibblers, $N)$ or as one meal (for one 4 h period) (meal-feeders, $M F$ ) daily $\dagger$

(Mean values for ten rats/group)

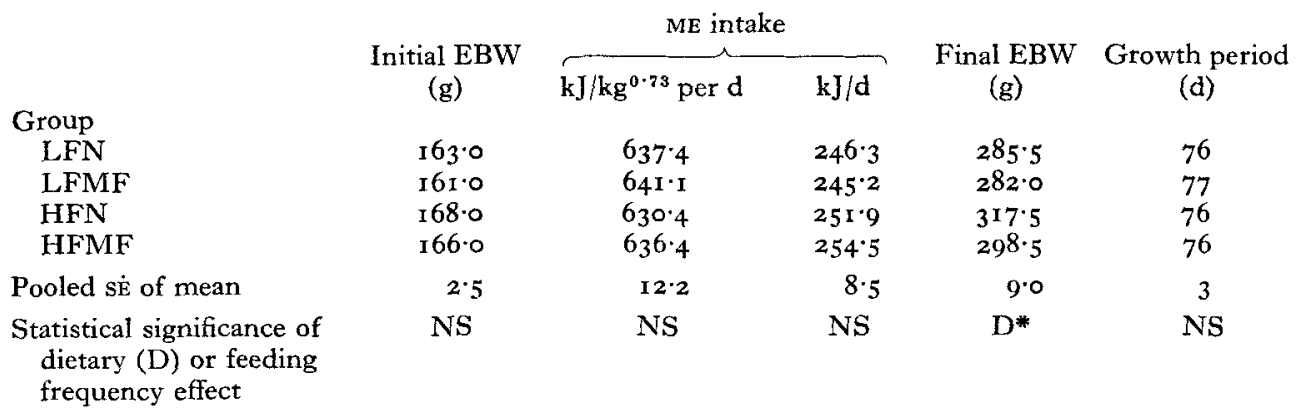

ME, metabolizable energy; NS, not significant.

* $\mathbf{P}<0.05$.

+ For details of diets and feeding regimens, see p. I6 and Table I.

The influence of the fat content of the diet on fat deposition in adipose tissues was determined by studying the fatty acid composition of epididymal and perirenal fat pads. Chloroform-methanol $(2: \mathrm{I}, \mathrm{v} / \mathrm{v})$ extracts of these tissues were methylated and the fatty acid methyl esters were then identified and the amounts of each determined using gas-liquid chromatography (Wood, 1973).

Plasma free fatty acid concentrations were determined using the procedure of Dole \& Meinertz (1960).

\section{Statistical methods}

The experiment had a balanced factorial design. Residual variance was estimated from a pooling of second and higher order interactions.

\section{RESULTS}

\section{Energy intake and EBW change}

The initial and final EBW and energy intakes for the groups of rats are shown in Table 2. The experimental period was $76 \mathrm{~d}$. The ME content of both diets was $0.94 \pm$ 0.003 of the gross energy for the twenty rats used. The ME intakes for the four groups during the growth experiment were similar when expressed on a $W^{0.73}$ basis. However, the rats given the high-fat diet grew more than those given the low-fat diet and the daily ME intake was slightly, but not significantly, greater for these animals. The energy intake of the rats was about $80 \%$ of the ad lib. level (assessed from previous studies in our laboratory with Sprague-Dawley rats of the same age and weight). 
Table 3. Regressions derived for 'initial slaughter' group* of twelve rats, from which the initial empty-body composition for the experimental animals was estimated

(Equation: $Y=\mathrm{a}+\mathrm{b} X$ )

\begin{tabular}{|c|c|c|c|c|c|}
\hline$X$ & $Y$ & a & b & $r^{2}$ & $\begin{array}{c}\text { Coefficient of } \\
\text { variation }\end{array}$ \\
\hline $\begin{array}{l}\text { Body-weight } \\
\text { at } 08.00 \text { hours }(\mathrm{g}) \dagger \\
\text { EBW (g) }\end{array}$ & $\begin{array}{l}\text { EBW }(\mathrm{g}) \\
\text { Protein (nitrogen } \times 6.25)\end{array}$ & $-28 \cdot 1$ & I. 10 & 0.98 & $1 \cdot 36$ \\
\hline & content $(\mathrm{g})$ & $-\mathrm{I}_{5} \cdot 8$ & 0.30 & 0.95 & $r \cdot 16$ \\
\hline EBW (g) & Water content (g) & $5^{6 \cdot 9}$ & 0.35 & 0.74 & $\mathrm{I} \cdot \mathrm{OO}$ \\
\hline EBW $(\mathrm{g})$ & Diethyl ether extract (g) & $-35 \cdot 9$ & 0.28 & 0.64 & II $\cdot 87$ \\
\hline EBW (g) & Energy $(\mathrm{kJ})$ & $-1838 \cdot 0$ & 18.44 & 0.84 & 3.71 \\
\hline
\end{tabular}

Chemical composition of bodies of rats and daily increments of chemical components

The equations from which the initial empty-body composition for the experimental rats was determined are given in Table 3 . The $r^{2}$ values indicated that a large proportion of the variation in chemical composition between the rats of the "initial slaughter' group could be explained by variation in EBW. The amount of diethyl ether extract (fat content) was the most variable component of the empty-body composition. These findings are similar to those of Reid, Bensadoun, Bull, Burton, Gleeson, Han, Joo, Johnson, McManus, Paladines, Stroud, Tyrrell, Van Niekerk \& Wellington (1968) who studied the body composition of sheep and pigs.

The chemical composition of the bodies of the rats at the end of the experimental period, for the two experimental diets and two feeding frequencies is shown in Table 4 . The diet and feeding frequency had no significant effects on the final water or protein $(\mathrm{N} \times 6.25)$ contents of the empty bodies of the rats, or the daily increments of these components. However, rats given the high-fat diet had higher concentrations of body fat and deposited more fat daily than those given the low-fat diet. The differences in final EBW and growth rate between rats given the low-fat and high-fat diets were therefore explained by the difference in fat deposition. Rats given the high-fat diet also had higher concentrations of body energy than those given the low-fat diet and their daily tissue gains contained significantly more energy. The daily storage of energy $(\mathrm{kJ} / \mathrm{d})$ as a percentage of the daily ME intake $(\mathrm{kJ} / \mathrm{d})$ was $10.29, \mathrm{II} \cdot 09, \mathrm{r} 3.03$ and II .85 for the LFN, LFMF, HFN and HFMF rats, respectively (pooled SE of mean $0.008)$. The effect of diet was significant $(P<0.05)$ but the effect of feeding frequency was not.

\section{Fat metabolism studies}

The body fat stores of the rats in the four groups were accumulated using different metabolic processes. For both epididymal and perirenal fat pads, lipogenesis from glucose was much greater for rats given the low-fat diet than for those given the highfat diet ('Table 5). Lipogenesis was also greatly increased as a result of meal-feeding with the low-fat diet but not with the high-fat diet. It should also be pointed out that 


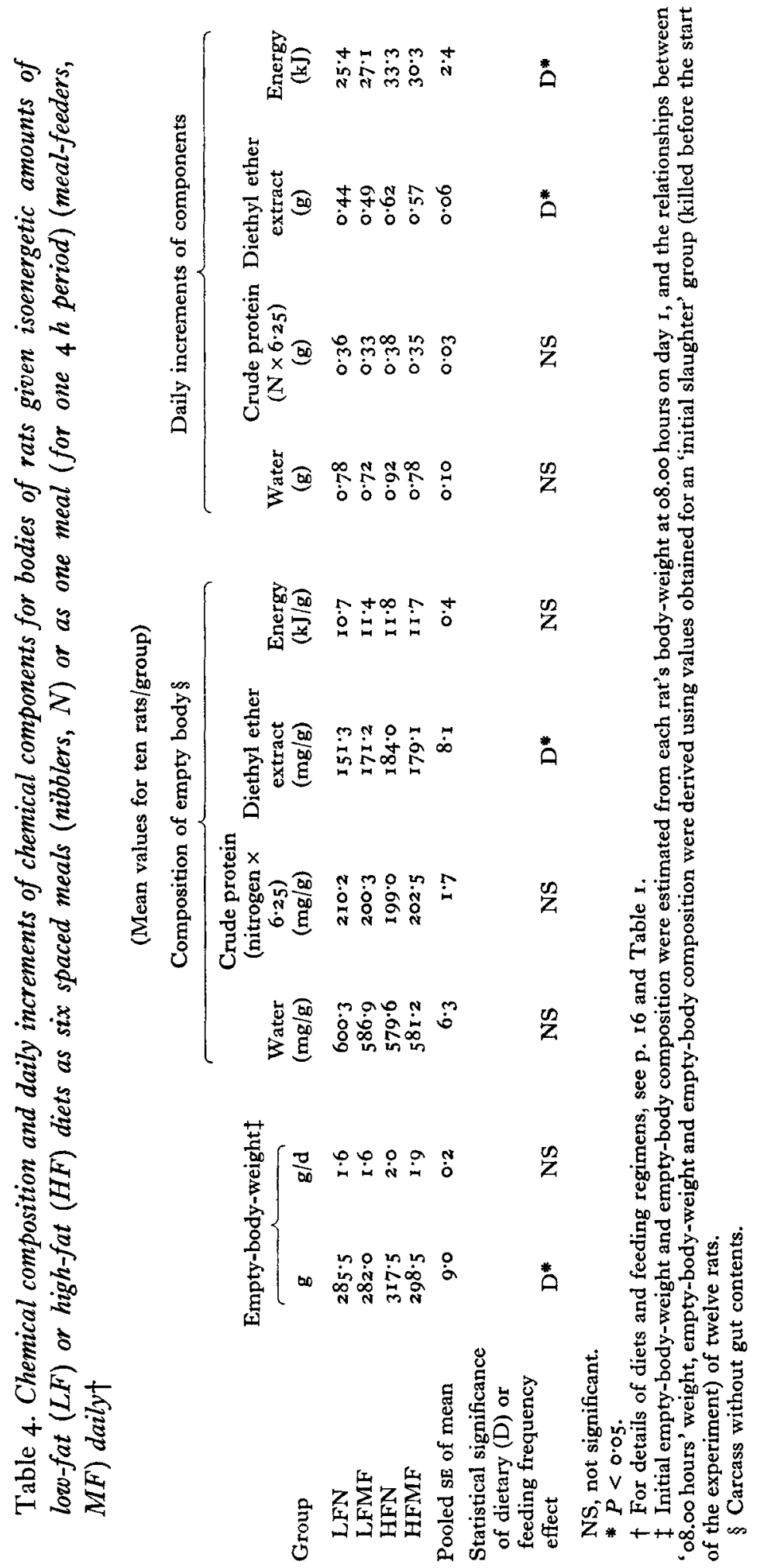


Table 5. Lipogenesis in fat pads from rats; the amount of radioactivity isolated as lipid from epididymal and perirenal fat pad slices following $2 h$ incubation $\dagger$ with $0.25 \mu \mathrm{Ci}$ $\beta-\mathrm{D}-\left[U-{ }^{14} \mathrm{C}\right]$ glucose using tissues removed from rats ${ }_{15} \mathrm{~h}$ after the last meal of a low-fat $(L F)$ or high-fat $(H F)$ diet given as six spaced meals (nibblers, $N)$ or as one meal (for one $4 h$ period) (meal-feeders, $M F$ ) daily $†$

\begin{tabular}{|c|c|c|c|c|}
\hline & \multicolumn{4}{|c|}{ (Mean values for ten rats/group) } \\
\hline & \multicolumn{2}{|r|}{ Epididymal } & \multicolumn{2}{|r|}{ Perirenal } \\
\hline Group & $\begin{array}{l}\text { Wet wt } \\
\text { (g) }\end{array}$ & $\begin{array}{l}\text { Lipid radioactivity } \\
\text { (counts/min per } g \\
\text { wet tissue })\left(\times 10^{-3}\right)\end{array}$ & $\begin{array}{c}\text { Wet wt } \\
\text { (g) }\end{array}$ & $\begin{array}{l}\text { Lipid radioactivity } \\
\text { (counts/min per } \mathrm{g} \\
\text { wet tissue) }\left(\times 10^{-3}\right)\end{array}$ \\
\hline LFN & 3.99 & ${ }_{13} 8$ & $5 \cdot 12$ & 94 \\
\hline LFMF & 4.02 & 320 & $5.5 I$ & 198 \\
\hline HFN & $4 \cdot 84$ & 37 & $7 \cdot 27$ & 29 \\
\hline HFMF & $4 \cdot 50$ & 57 & 6.44 & 36 \\
\hline Pooled SE of mean & 0.29 & 29 & 0.42 & 22 \\
\hline $\begin{array}{l}\text { Statistical significance of dietary } \\
\text { (D) or feeding frequency (F) } \\
\text { effect }\end{array}$ & NS & $\begin{array}{l}D^{* * * *} \\
F^{* * * *}\end{array}$ & $D^{* *}$ & $\begin{array}{l}D^{* * * *} \\
F^{* * * *}\end{array}$ \\
\hline
\end{tabular}

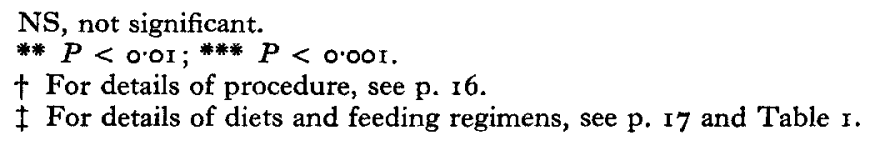

the small differences between the amount of lipogenesis for the epididymal and perirenal fat pads for all groups, and between groups HFN and HFMF for both tissues were eliminated when the results for the amount of radioactivity were expressed on a total fat pad basis, indicating that the amount of lipogenesis/unit tissue weight decreases as the fat content of the tissue increases. The inhibition of lipogenesis in rats given the high-fat diet was accompanied by a direct incorporation of dietary fatty acids into adipose tissues (Table 6). The maize oil used as the source of dietary fat had the following fatty acid composition $(\mathrm{mmol} / \mathrm{mol})$, which closely resembled that of the fat pads of rats given the high-fat diet: 16:0 I I 5, I8:0 20, I8: I $273,18: 2586$. The formation of body fat from dietary fat resulted in a greater deposition of chemical fat in epididymal and perirenal fat pads as well as in the total empty bodies of the rats given the high-fat diet (Table 4) and was associated with their more efficient utilization of energy for growth (Table 2). As for the body composition results, there was a slight indication that LFMF rats, as a result of their greatly increased capacity for lipogenesis, had larger fat pads than LFN rats, with a correspondingly higher saturated fatty acid composition. Conversely HFMF rats had slightly smaller fat pads than HFN rats with a significantly lower concentration of the main dietary fatty acid, $18: 2$.

The plasma free fatty acid concentrations are shown in Table 7 . These were greater for meal-feeders given both diets, showing that there was a greater mobilization of fat from adipose tissue of these rats at the time of slaughter. 
Table 6. Fat content and fatty acid composition of epididymal and perirenal fat pads from rats given isoenergetic amounts of low-fat $(L F)$ or high-fat $(H F)$ diets as six spaced meals (nibblers, $N$ ) or as one meal (for one $4 h$ period) (meal-feeders, $M F$ ) daily $\dagger$

(Mean values for ten rats/group)

Diethyl ether extract $(\mathrm{g})$ Fatty acid composition of fat pads $(\mathrm{mg} / \mathrm{g}) \ddagger$

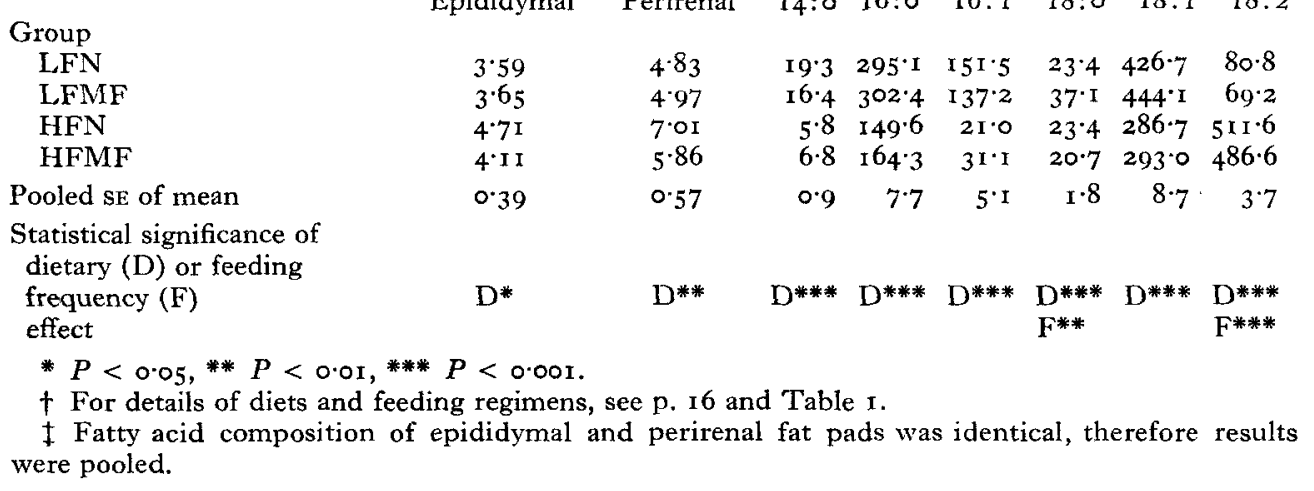

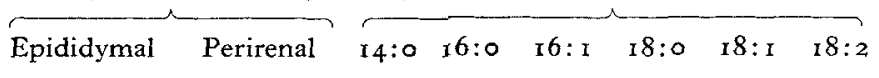

Table 7. Digestive organ weights and contents, and plasma free fatty acid $(F F A)$ concentrations for rats given isoenergetic amounts of low-fat $(L F)$ or high-fat $(H F)$ diets as six spaced meals (nibblers, $N$ ) or as one meal (for one $4 h$ period) (meal-feeders, $M F$ ) daily $\dagger$

(Mean values for ten rats/group)

\begin{tabular}{|c|c|c|c|}
\hline & $\begin{array}{l}\text { Wt of stomach } \\
\text { and small intestine } \\
\text { (g dry wt) }\end{array}$ & $\begin{array}{l}\text { Contents of stomach } \\
\text { and small intestine } \\
\qquad(\mathrm{g} \text { dry wt) }\end{array}$ & $\begin{array}{l}\text { Plasma FFA } \\
(\mathrm{mmol} / \mathrm{l})\end{array}$ \\
\hline \multicolumn{4}{|l|}{ Group } \\
\hline LFN & I.99 & 0.27 & 0.213 \\
\hline LFMF & $2 \cdot 21$ & $I \cdot 05$ & 0.242 \\
\hline HFN & $2 \cdot 02$ & 0.28 & 0.225 \\
\hline HFMF & $2 \cdot 13$ & 0.73 & 0.253 \\
\hline Pooled SE of mean & 0.05 & $0.1 I$ & 0.120 \\
\hline $\begin{array}{l}\text { Statistical significance of dietary or } \\
\text { feeding frequency }(\mathrm{F}) \text { effect }\end{array}$ & $F^{*}$ & $\mathrm{~F}^{* * * *}$ & $\mathrm{~F}^{*}$ \\
\hline
\end{tabular}

\section{Digestive organs and their contents}

The adaptations made by the rats to less frequent feeding include modifications to their digestive system (Tepperman \& Tepperman, 1964). The results shown in Table 7 indicated that the meal-feeders in the present study had heavier stomachs and small intestines than the nibblers and also that growth of the digestive organs had been stimulated in these rats as a result of their need to maximize food intake in a limited time period. As previously noted, however, this did not lead to an increased availability of dietary energy.

The greater weight of stomach and small intestine contents for meal-feeders was a result of their larger final meal and suggested that absorption of nutrients may still have been occurring in these rats $I_{5} \mathrm{~h}$ after that meal. 


\section{DISCUSSION}

The results for initial body composition showed that the amount of body fat was less rigidly associated with body-weight than the amount of protein or water. This suggested that body fatness could be influenced more than these other components by dietary manipulation. The treatments that were subsequently imposed on the rats showed this to be correct although the influence of the fat content of the diet on body fatness was much greater than the influence of feeding frequency. The high-fat diet increased fat accumulation and, through this, body-weight gain and the efficiency of utilization of energy. Schiemann (1969) reported similar effects and found that the greater efficiency was entirely the result of the lower energy cost of incorporating dietary fat into body fat. In particular, there was no change in the energy requirements for maintenance.

Some of the effects of meal-feeding were the same for the rats given the two diets. Both groups of meal-feeders had heavier stomachs and small intestines and both had higher plasma free fatty acid levels i $5 \mathrm{~h}$ after their final meal. Body fat may have been acting, therefore, as a relatively more important energy source for both groups.

However, the other responses to meal-feeding were apparently dependent on the diet. Adipose tissues from LFMF rats had greatly increased rates of lipogenesis from glucose. In terms of body fatness this was counteracted by the greater fat mobilization occurring $\mathrm{I}_{5} \mathrm{~h}$ after the daily meal. The net effect of this fluctuating pattern of fat metabolism was that after $76 \mathrm{~d}$ meal-feeders were slightly, but not significantly, fatter than nibblers and their daily weight gains contained slightly more energy. These results are different from those of Cohn et al. (1955) who force-fed meal-feeders with two daily meals containing a quantity of food equal to the ad lib. intake. In the latter experiment, meal-feeders were considerably fatter and more efficient than nibblers. However, the results are similar to those of Friend (1967) who also fed both groups isoenergetic meals, but for a shorter time $(3 \circ \mathrm{d})$. It therefore appears that an ad lib. intake is necessary to produce increased fatness in meal-fed rats although many metabolic adaptations to the unusual feeding pattern are found when the intake is only $80 \%$ of the ad lib. value.

HFMF rats were required to adjust to the unusual feeding pattern for the same reasons as LFMF rats. However, their growth, body composition and energy storage were not significantly different from those for HFN rats and in almost all respects the effects of feeding frequency were opposite to those found for the low-fat diet. Thus HFMF rats grew less quickly than HFN rats, deposited less fat and energy, and incorporated significantly less dietary fatty acid $18: 2$ into adipose tissues. There was therefore no evidence that the efficiency of the transformation of dietary fat into body fat was increased as a result of meal-feeding, rather the reverse.

It has been suggested that body composition in rats, particularly the fat content, can be influenced more by nutritional methods than the body composition of sheep and pigs (Reid et al. I968). The present results indicate that the daily rate of fat deposition in rats eating several small meals can be increased by about $40 \%$ by giving them isoenergetic amounts of a diet containing $140 \mathrm{~g}$ fat $/ \mathrm{kg}$ rather than Io $\mathrm{g}$ fat $/ \mathrm{kg}$. 
Meal-feeding increases the rate of fat deposition slightly when the low-fat diet is given but does not improve the already efficient utilization of the high-fat diet.

These investigations were supported in part by research grant AM-02889 from the National Institute of Arthritis and Metabolic Diseases, US Public Health Service, Bethesda, Maryland, USA. We also wish to thank Dr D. Lister and Dr M. B. Enser of the Meat Research Institute, Bristol, for helpful discussion of the results.

\section{REFERENCES}

Association of Official Agricultural Chemists (1955). Official Methods of Analysis, 8th ed. Washington, DC: Association of Official Agricultural Chemists.

Cohn, C., Shrago, E. \& Joseph, D. (1955). Am. F. Physiol. r8o, 503.

Dole, V. P. \& Meinertz, H. (1960). F. biol. Chem. 235, 2595.

Folch, J., Lees, M. \& Sloane Stanley, G. H. (1957). F. biol. Chem. 226, 497.

Friend, D. W. (1967). Can. \%. Physiol. Pharmac. 45, 367.

Hollifield, G. \& Parson, W. (1962). F. clin. Invest, 41, 245.

Jansen, G. R., Hutchison, C. F. \& Zanetti, M. E. (1 966). Biochem. F. 99, 323.

Leveille, G. A. \& Hanson, R. W. (1966). F. Lipid Res. 7, 46.

O'Hea, E. K. \& Leveille, G. A. (1968). Comp. Biochem. Physiol. 26, i I I.

Reid, J. T., Bensadoun, A., Bull, L. S., Burton, J. H., Gleeson, P. A., Han, I. K., Joo, Y. D., Johnson, D. E., McManus, W. R., Paladines, O. L., Stroud, J. W., Tyrrell, H. F., Van Niekerk, B. D. H. \& Wellington, G. W. (1968). Body Composition in Animals and Man, p. 19. Washington, DC: National Academy of Sciences.

Schiemann, R. (1969). Publs Eur. Ass. Anim. Prod. no. I 2, p. 3 I.

Tepperman, H. M. \& Tepperman, J. (1964). Fedn Proc. Fedn Am. Socs exp. Biol. $23,73$.

Wiley, J. H. \& Leveille, G. A. (I970). F. Nutr. 100, 1073.

Wood, J. D. (1973). Anim. Prod. 17, 281. 